\title{
KEEFEKTIFAN TEKNIK SELF-INSTRUCTION UNTUK MENINGKATKAN KEPERCAYAAN DIRI SISWA SMP
}

\author{
Kasa Fiorentika, Djoko Budi Santoso, Irene Maya Simon \\ Bimbingan dan Konseling-Fakultas Ilmu Pendidikan-Universitas Negeri Malang-Jl.Semarang No. 5 Malang \\ E-mail:kasafiorentika@gmail.com
}

\begin{abstract}
The objective of this research is to know the effectiveness of self -instruction to improve the self confidence on Junior High School students. Data were collected using the inventory of confidence and analyzed with the Wilcoxon test through SPSS. The results show that there are five students who have a low level of confidence. Those students were given counseling group using self -instruction techniques, students are given a pretest - posttest to measure the effectiveness of the technique. the result show that students increase confidence after attending group counseling using self- instruction techniques.
\end{abstract}

Keywords: self-confidence; self -instruction; junior high school students

\begin{abstract}
Abstrak: Tujuan dari penelitian ini adalah mengetahui keefektifan teknik self-instruction untuk meningkatkan kepercayaan diri siswa SMP. Data dikumpulkan menggunakan inventori kepercayaan diri dan dianalisis dengan uji Wilcoxon menggunakan SPSS. Hasil penelitian menunjukkan ada lima siswa yang mempunyai tingkat kepercayaan diri rendah. Siswa tersebut diberikan konseling kelompok dengan teknik self-instruction, siswa diberikan pretest-posttest untuk mengukur keefektifan teknik yang diberikan. Hasilnya menunjukkan bahwa siswa mengalami peningkatan kepercayaan diri setelah mengikuti konseling kelompok dengan teknik self-instruction.
\end{abstract}

Kata kunci: kepercayaan diri; self-instruction; siswa SMP

Siswa sekolah menengah pertama menurut usianya berada dalam masa remaja. Dalam masa ini remaja mencoba berbagai hal dalam pekerjaan, pendidikan dan mereka berusaha menemukan jati diri (Slavin, 2008:67). Terkadang dalam mencoba berbagai hal baru dalam hidupnya, ada beberapa hal yang tidak sesuai dengan apa yang diharapkan oleh remaja. Hal ini dapat memberikan dampak bagi pembentukan konsep diri remaja pada akhirnya berakibat pada kepercayaan dirinya.

Kegiatan sehari-hari remaja banyak dihabiskan di luar rumah bersama dengan teman-teman sebaya. Karena itu pengaruh teman sebaya terhadap sikap, pembicaraan, minat, penampilan, dan perilaku remaja sangat besar dibandingkan dengan pengaruh keluarga. Penerimaan teman sebaya sangat mempengaruhi sikap dan perilaku. Remaja beranggapan bahwa dengan diterimanya mereka oleh teman sebaya maka berhasil dalam berinteraksi dengan lingkungan dan menimbulkan percaya diri (Hurlock, 2005:2013). 
Perkembangan yang paling menonjol dari masa peralihan salah satunya adalah pencarian jati diri. Seorang remaja harus mempunyai kepercayaan diri agar membantu dalam menjalankan tugas perkembangannya. Misalnya dalam pembentukan citra diri ataupun jati diri pada remaja, dan proses penyesuaian diri terhadap lingkungan sosial. Papalia (2008:520) mengatakan bahwa masa remaja merupakan fase peralihan individu dari masa anak-anak hingga dewasa. Remaja mengalami pertumbuhan cepat, secara fisik, psikis dan sosial.

Kepercayaan diri adalah hal yang seharusnya dimiliki remaja untuk mencapai kesuksesan. Terkadang remaja tidak menyadari bahwa kurangnya kepercayaan diri dapat menghambat kegiatan sehari-hari. Sikap remaja yang menunjukkan rendahnya kepercayaan diri, seperti: selalu ragu-ragu dalam melakukan suatu hal, mudah cemas, tidak memiliki keyakinan, cenderung menghindar, menutup diri, kurang inisiatif, mudah patah semangat, takut untuk tampil di depan orang banyak, dan lain-lain akan menghambatnya untuk melakukan sesuatu. Menurut Lauster (2008:14), dalam hubungan dengan orang lain, rasa rendah diri terlihat sebagai rasa malu, kebingungan, dan rendah hati yang berlebihan. Oleh karena itu, rendahnya rasa percaya diri bisa menyebabkan masalah penyesuaian diri remaja dengan lingkungan sekitar.

Siswa yang memiliki kepercayaan diri rendah akan memiliki sifat dan perilaku antara lain: tidak mau mencoba suatu hal yang baru, merasa tidak dicintai dan tidak diinginkan, punya kecenderungan melempar kesalahan pada orang lain, memiliki emosi yang kaku dan disembunyikan, mudah mengalami rasa frustasi dan tertekan, meremehkan bakat dan kemampuan diri sendiri, serta mudah terpengaruh oleh orang lain. Menurut Sugiarto (2009:114), ciri-ciri seorang yang kurang percaya diri yang dapat kita amati adalah: sering menghindari kontak mata (menunduk/membuang pandangan ke arah lain), sering mengamuk untuk melepaskan kecemasan, tidak banyak bicara (sering menjawab secukupnya apabila ditanya, seperti: "ya" atau "tidak", bahkan hanya mengangguk untuk kegiatan-kegiatan di kelas maupun di luar kelas (pasif), tidak mau meminta pertolongan atau bertanya pada orang yang belum dikenal baik, mengalami demam panggung di saat-saat tertentu dan sulit berbaur dengan lingkungan/situasi baru (butuh waktu yang cukup lama untuk menyesuaikan diri).

Menurut Lindenfield (1997:3), orang yang percaya diri adalah orang yang merasa puas dengan dirinya. Orang yang mempunyai rasa percaya diri tinggi akan selalu bersyukur karena merasa puas dengan apa yang ada pada dirinya. Orang yang tidak percaya diri memiliki konsep diri yang negatif dan kurang percaya pada kemampuannya sehingga sering menutup diri. Oleh karena itu, masalah kepercayaan diri pada individu menjadi prioritas yang harus dibangun untuk mencapai penyesuaian diri secara maksimal.

Berbagai layanan dan strategi dapat dilakukan untuk meningkatkan kepercayaan diri siswa. Salah satunya adalah teknik self-instruction. Self-instruction merupakan salah satu teknik dalam Cognitive Behavior Therapy (CBT) yang dikembangkan oleh Meichenbaum. Cognitive Behavior Therapy merupakan pendekatan sebagai sebuah integrasi dari metode-metode kognitif dan perilaku (Rahmawati, 2009:115).

Self-instruction bertujuan untuk dapat membentuk ulang pola-pola kognitif, asumsi-asumsi, keyakinan-keyakinan, dan penilaian-penilaian irasional, merusak dan menyalahkan diri sendiri. Konselor dapat menguji ulang keyakinan siswa terhadap diri mereka dengan berbagai teknik persuasi verbal dan aktivitas yang diberikan secara berulang-ulang sampai pada akhirnya siswa dapat melakukannya untuk diri sendiri (Cormier \& Nurius, 2003:353).

Keefektifan penggunaan teknik self-instruction dalam meningkatkan kepercayaan diri siswa didukung dengan hasil-hasil penelitian yang lain. Prasetyo (2013) mengemukakan bahwa teknik selfinstruction efektif untuk menurunkan tingkat kecemasan siswa dalam menghadapi ujian, Widiyanti (2013) dalam penelitiannya juga mengemukakan bahwa self-instruction dapat meningkatkan selfefficacy dalam belajar siswa, Firmansyah (dalam Prasetyo, 2013) mengungkapkan bahwa selfinstruction dapat mereduksi gejala kejenuhan dalam belajar siswa. Pada kesempatan ini peneliti akan meneliti tentang keefektifan self-instruction untuk meningkatkan kepercayaan diri siswa. 


\section{METODE}

Penelitian menggunakan pendekatan kuantitatif. Rancangan penelitian yaitu penelitian Pre Experimential Design. Peneliti menggunakan rancangan Pre Experimental Design karena belum merupakan eksperimen sungguh-sungguh dan masih terdapat variabel luar yang ikut berpengaruh terhadap terbentuknya variabel dependen. Desain yang digunakan adalah one group pretest-posttest. Penggunaan desain ini untuk mengukur perubahan sebelum dan sesudah diberikan perlakuan.

Penelitian menggunakan teknik penentuan subjek jenis purposive sampling dimana pemilihan kelompok subjek didasarkan pada karakteristik yang sudah ditentukan dan diketahui terlebih dahulu berdasarkan ciri atau sifatnya. Penempatan pada kelompok eksperimen dilakukan dengan menggunakan purposive sampling, yaitu teknik penentuan sampel dengan pertimbangan tertentu (Sugiyono, 2008:85).

Penelitian dilakukan dengan memberikan pretest sebelum dilakukan treatment dan pemberian posttest setelah treatment. Pretest dilakukan dengan memberikan inventori kepercayaan diri kepada subjek penelitian sebelum mendapatkan treatment dengan maksud untuk mengetahui tingkat kepercayaan diri subjek. Pada tahapan kedua peneliti memberikan treatment kepada subjek untuk membantu meningkatkan kepercayaan diri siswa. Treatment diberikan kepada subjek penelitian yang memiliki kepercayaan diri rendah. Treatment dilakukan dengan menggunakan teknik self-instruction dalam setting kelompok. Dalam pelaksanaan treatment, pertama peneliti membantu siswa menggali masalah-masalah yang berkaitan dengan kepercayaan diri. Prosedur konseling yang dilakukan mengikuti langkah-langkah yang ada pada panduan konseling dengan teknik self-instruction. Durasi yang dilakukan tiap langkah sekitar 45 menit dalam setiap kali pertemuan. Pada tahapan terakhir, posttest dilakukan setelah subjek penelitian diberikan treatment melalui pemberian inventori kepercayaan diri dengan maksud untuk mengetahui perubahan kepercayaan diri subjek penelitian dan untuk mengetahui keberhasilan selama dilakukan treatment.

Instrumen yang digunakan peneliti adalah inventori kepercayaan diri. Panduan konseling yang di dalamnya terdapat rancangan untuk pelaksanaan treatment. Format instruksi diri dan lembar refleksi untuk mengetahui sejauh mana subjek penelitian mengetahui materi yang diberikan. Inventori kepercayaan diri digunakan untuk mengukur tingkat kepercayaan diri siswa. Panduan konseling digunakan untuk pelaksanaan konseling kelompok bagi siswa.

Pengumpulan data penelitian dilaksanakan dengan memberikan inventori kepercayaan diri pada kelas VII G SMPN 20 Malang sejumlah 30 siswa. Setelah pemberian pretest pertama terjaring empat siswa yang memiliki tingkat kepercayaan diri rendah dan satu siswa yang memiliki tingkat kepercayaan diri sedang. Lima siswa tersebut diberikan pretest sekali lagi untuk mengukur konsistensi tingkat kepercayaan dirinya. Setelah hasil pemberian pretest kegiatan selanjutnya adalah pelaksanaan konseling kelompok dengan teknik self-instruction selama tiga kali pertemuan. Pemberian posttest diberikan untuk mengukur hasil treatment yang diberikan. Hasil dari pretest-posttest akan digunakan untuk mengukur keefektifan teknik self-instruction yang diberikan.

Analisis data merupakan langkah penting dalam kegiatan penelitian. Analisis data dapat membuktikan hipotesis yang telah ditemukan. Menurut Sugiyono (2008:147) kegiatan yang dilakukan dalam analisis data yang dilakukan adalah (1) analisis data kuantitatif(analisis data pretest dan posttest) dan (2) analisis data untuk menguji hipotesis yang telah diajukan. Dalam melakukan analisis data tersebut menggunakan program SPSS 16.0 for Windows untuk memudahkan dalam perhitungannya. Penelitian menggunakan dua analisa data, yang pertama analisa data kuantitatif dan analisa data untuk menguji hipotesis.

Kegiatan yang dilakukan dalam analisis data kuantitatif adalah penskoran dan pentabulasian data. Penskoran dilakukan dengan memberikan skor pada setiap butir pernyataan sesuai dengan jawaban yang diberikan oleh subjek penelitian. Pemberian skor berdasarkan atas klasifikasi butir positif dan negatif. Setelah melakukan penskoran, dilanjutkan dengan pentabulasian data dengan cara memasukkan data yang diperoleh dari skor yang sudah ada dalam tabel. Kemudian dikelompokan menjadi seperangkat data berdasarkan hasil prestest dan posttest. Dalam menganalisis data, peneliti 
Tabel 1 Data Hasil Penjaringan Subjek Penelitan

\begin{tabular}{lll}
\hline Subjek & Skor & Kategori \\
\hline AS & 85 & Rendah \\
AT & 70 & Rendah \\
HZ & 76 & Rendah \\
RP & 82 & Rendah \\
YN & 98 & Sedang \\
\hline
\end{tabular}

menggunakan statistik deskriptif yang akan menghasilkan tingkatan kategori kepercayaan diri tinggi, sedang dan rendah.

Pengujian hipotesis dilakukan dengan membandingkan tingkat kepercayaan diri subjek penelitian sebelum dan sesudah diberikan treatment. Keefektifan pengaruh treatment yang diberikan terhadap tingkat kepercayaan diri dapat dilihat dari perbedaan antara hasil pretest dan posttest. Untuk lebih meyakinkan, digunakan analisis statistic non parametric dengan menggunakan uji Wilxocon dengan bantuan SPSS. Hipotesis dinyatakan diterima jika nilai signifikansi $<0,05$ yang berarti terdapat perbedaan tingkat kepercayaan diri antara sebelum pemberian treatment dan setelah pemberian. Namun jika nilai signifikansi $>0,05$ berarti tidak terdapat perbedaan frekuensi antara sebelum pemberian treatment dan setelah pemberian atau dengan kata lain hipotesis yang diajukan ditolak.

\section{HASIL DAN PEMBAHASAN}

\section{Data Kualitatif}

Rendahnya sikap kepercayaan diri siswa yang terjadi di SMP Negeri 20 Malang khususnya kelas VII terlihat jelas dari perilaku siswa yang menunjukkan gejala-gejala seperti malu untuk berbicara di depan kelas, jarang bertanya pada guru, menghindari pembicaraan dengan teman dan diam di kelas, dari gejala tersebut dapat diartikan bahwa siswa-siswa kelas VII SMP Negeri 20 Malang menunjukkan gejala-gejala atau tingkah laku yang kurang percaya diri. Data hasil penjaringan subyek penelitian disajikan dalam tabel 1 .

Tempat penelitian adalah di SMP Negeri 20 Malang, yang berada di jalan R. Tumenggung Suryo No. 38 Malang. Subjek penelitian berjumlah 5 siswa. Pemberian pretest berupa inventori kepercayaan diri dilaksanakan selama dua kali, pretest yang pertama dilakukan kepada seluruh siswa kelas VII G yang merupakan populasi dari penelitian ini, prestest pertama dilaksanakan hari senin tanggal 29 Februari 2016 jam 12.00 WIB pada 30 siswa. Kemudian dilanjutkan pada 5 siswa yang merupakan hasil penjaringan dari hasil skor pretest pertama yang memiliki kepercayaan diri rendah. Dilaksanakan pada hari senin tanggal 07 Maret 2016 pada pukul 12 siang.

Setelah pretest dilakukan, dilakukan juga posttest yang berguna untuk mengukur sejauh mana hasil dari penerapan teknik self-instruction dalam meningkatkan kepercayaan diri siswa yang diwujudkan dalam bentuk skor. Posttest dilakukan pada akhir pelaksanaan treatment yaitu pada hari Rabu tanggal 30 Maret 2016. Setiap treatment yang dilakukan merupakan penerapan pelaksanaan konseling kelompok dengan teknik self-instruction sesuai dengan aspek yang telah dijabarkan pada kisi-kisi inventori kepercayaan diri.

Pengamatan terhadap subjek penelitian dilakukan oleh peneliti pada saat pemberian treatment. Kegiatan ini dilakukan sebelum, selama, dan sesudah berjalannya proses pemberian treatment menggunkan teknik self-instruction selama 3 kali pertemuan. Pelaksanaan treatment ini dilakukan mulai hari Senin, 14 Maret 2016 sampai 30 maret 2016. Hal yang diamati selama pelaksanaan konseling adalah tingkah laku siswa yang berhubungan dengan sikap percaya diri. Misalnya, sikap siswa ketika memperkenalkan diri dihadapan teman-teman, memimpin doa, menyampaikan pendapat dan bertanya.

Tempat kegiatan adalah ruang Bimbingan dan Konseling SMP Negeri 20 Malang dan subjek yang diamati berjumlah 5 siswa. Selama proses pelaksaan konseling, peneliti membuat setting tempat 
Tabel 2 Instruksi Diri Siswa pada Konseling Pertama

\begin{tabular}{|c|c|c|}
\hline Subjek & Pikiran yang Muncul & Instruksi Diri \\
\hline$\overline{\mathrm{AS}}$ & $\begin{array}{l}\text { Cara memakai kerudung saya kurang menarik } \\
\text { dibandingkan dengan teman-teman saya }\end{array}$ & $\begin{array}{l}\text { Setiap siswa mempunyai gaya memakai } \\
\text { kerudung yang berbeda-beda, dan saya nyaman } \\
\text { dengan gaya kerudung yang saya kenakan } \\
\text { sekarang }\end{array}$ \\
\hline AT & Penampilan saya kurang menarik & $\begin{array}{l}\text { Penampilan diri setiap orang mempunyai gaya } \\
\text { atau style masing-masing, jadi saya tidak perlu } \\
\text { malu dengan penampilan saya }\end{array}$ \\
\hline $\mathrm{HZ}$ & $\begin{array}{l}\text { Saya malu dengan diri saya ketika memimpin } \\
\text { doa di depan kelas }\end{array}$ & $\begin{array}{l}\text { Saya tidak perlu malu karena semua teman saya } \\
\text { juga pernah merasakan di depan kelas } \\
\text { memimpin doa }\end{array}$ \\
\hline $\mathrm{RP}$ & $\begin{array}{l}\text { Tubuh saya pendek dan saya malu ketika semua } \\
\text { teman memperhatikan diri saya }\end{array}$ & $\begin{array}{l}\text { Saya tidak perlu malu dengan tubuh saya yang } \\
\text { pendek karena masih ada teman yang lebih } \\
\text { pendek dari saya }\end{array}$ \\
\hline YN & $\begin{array}{l}\text { Saya adalah orang yang mempunyai kulit hitam, } \\
\text { saya malu ketika harus maju kedepan kelas } \\
\text { karena pasti dilihat oleh semua teman saya }\end{array}$ & $\begin{array}{l}\text { Saya tidak perlu malu dengan warna kulit saya, } \\
\text { karena setiap orang mempunyai warna kulit } \\
\text { yang berbeda antara satu dengan yang lain }\end{array}$ \\
\hline
\end{tabular}

\section{Tabel 3 Instruksi Diri Siswa pada Konseling Kedua}

\begin{tabular}{|c|c|c|}
\hline Subjek & Pikiran yang muncul & Instruksi Diri \\
\hline AS & $\begin{array}{l}\text { Saya takut salah ketika mengerjakan soal di } \\
\text { papan tulis }\end{array}$ & $\begin{array}{l}\text { Jawaban salah tidak apa-apa yang } \\
\text { penting saya sudah mencoba }\end{array}$ \\
\hline AT & $\begin{array}{l}\text { Saya takut ketika menanyakan pelajaran } \\
\text { yang belum saya pahami kepada teman }\end{array}$ & $\begin{array}{l}\text { Sebaiknya saya menanyakan apa yang } \\
\text { belum saya pahami kepada teman saya } \\
\text { agar saya bisa mengerjakan saat ulangan }\end{array}$ \\
\hline $\mathrm{HZ}$ & $\begin{array}{l}\text { Saya takut ketika akan mengikuti } \\
\text { ekstrakurikuler musik, saya rasa tidak } \\
\text { mempunyai kemampuan di bidang tersebut }\end{array}$ & $\begin{array}{l}\text { Saya mengikuti ekstrakurikuler musik } \\
\text { karena saya ingin mengasah kemampuan } \\
\text { saya, meskipun saya kurang terampil } \\
\text { saya akan mencoba }\end{array}$ \\
\hline $\mathrm{RP}$ & $\begin{array}{l}\text { Saya selalu berpikiran negatif pada diri saya } \\
\text { sendiri, bahwa saya adalah orang yang } \\
\text { selalu gagal }\end{array}$ & $\begin{array}{l}\text { Saya berusaha menerima kegagalan itu } \\
\text { sebagai usaha untuk mendapatkan } \\
\text { keberhasilan }\end{array}$ \\
\hline YN & $\begin{array}{l}\text { Saya adalah yang mudah putus asa ketika } \\
\text { mengalami kegagalan }\end{array}$ & $\begin{array}{l}\text { Kegag alan yang saya alami bukan berarti } \\
\text { saya tidak mampu, tetapi saya perlu } \\
\text { meningkatkan lagi usaha saya }\end{array}$ \\
\hline
\end{tabular}

duduk subjek penelitian senyaman mungkin sehingga siswa dapat dengan mudah untuk mengikuti kegiatan konseling. Peneliti membuat posisi tempat duduk siswa sepeti huruf U agar memudahkan proses pengamatan terhadap seluruh siswa dan membuat siswa menjadi fokus dalam mengikuti seluruh kegiatan konseling. Kegiatan berlangsung selama 45 menit yang diawali dengan pemaparan kejadian yang dialami siswa berkaitan dengan kepercayaan diri, dilanjutkan dengan pelatihan instruksi diri dan diakhiri dengan refleksi tentang pelaksanaan konseling sekaligus pemberian home work. Topik yang dibahas dalam konseling dipilih berdasarkan skor terendah dari hasil pretest. Jadi topik pada setiap pertemuan berbeda-beda sesuai dengan indikator kepercayaan diri.

Kegiatan dimulai dengan satu-persatu subjek menceritakan kejadian yang pernah dialami atau tindakan yang berkaitan dengan gejala-gejala yang timbul. Apa yang mereka alami, apa yang mereka rasakan dari pengalaman tersebut. Setelah masing-masing subjek menyampaikan kejadian- yang pernah dialami, selanjutnya pengisian lembar instruksi diri yang dilanjutkan dengan pelatihan self-instruction atau instruksi diri untuk meningkatkan kepercayaan diri. Setelah pelaksanaan pelatihan selesai maka siswa diajak untuk merefleksi dari pelaksanaan kegiatan konseling ini serta melakukan perencanaan perilaku baru sesuai dengan pemikiran positif yang telah dimunculkan. Akhir kegiatan setiap siswa 


\section{Tabel 4 Instruksi Diri Siswa pada Pertemuan Ketiga}

\begin{tabular}{lll}
\hline Subjek & \multicolumn{1}{c}{ Piki ran yang muncul } & \multicolumn{1}{c}{ Instruksi Diri } \\
\hline AS & $\begin{array}{l}\text { Saya tidak terampil dalam } \\
\text { berko munikas i, lebih baik diam daripada } \\
\text { saya malu }\end{array}$ & $\begin{array}{l}\text { Setiap orang memiliki ketrampilan } \\
\text { berkomunikasi yang berbeda-beda, akan } \\
\text { lebih baik jika saya mencoba untuk } \\
\text { berbicara daripada diam }\end{array}$ \\
AT & $\begin{array}{l}\text { Saya tidak berani menyampaikan } \\
\text { pendapat ketika sedang dalam diskusi } \\
\text { kelompok }\end{array}$ & $\begin{array}{l}\text { Saya berusaha untuk mencoba berpendapat } \\
\text { dalam setiap diskusi kelo mpok untuk } \\
\text { melatih keberanian saya }\end{array}$ \\
& $\begin{array}{l}\text { Saya kurang terampil dalam menjawab } \\
\text { pertanyaan dari guru }\end{array}$ & $\begin{array}{l}\text { Saya akan berusaha menjawab pertanyaan } \\
\text { guru sesuai dengan kemampuan saya }\end{array}$ \\
HZ & $\begin{array}{l}\text { Saya kurang terampil dalam } \\
\text { berko munikasi jadi ketika saya berbicara } \\
\text { dengan teman saya cenderung banyak } \\
\text { diam dan menghindari pandangannya }\end{array}$ & $\begin{array}{l}\text { Saya berusaha untuk dapat memandang } \\
\text { wajah teman saya ket ika sedang berbicara }\end{array}$ \\
& $\begin{array}{l}\text { Saya kurang percaya diri ket ika disuruh } \\
\text { maju kedepan kelas untuk menjawab } \\
\text { pertanyaan dari guru }\end{array}$ & $\begin{array}{l}\text { Saya berusaha untuk berani maju ke depan } \\
\text { kelas, dan yakin akan jawaban saya }\end{array}$ \\
& YN &
\end{tabular}

Tabel 5 Perubahan Skor Pretest dan Posttest

\begin{tabular}{llll}
\hline Siswa & Skor Pretest & Skor Posttest & Perubahan Skor \\
\hline AS & 83 & 144 & 63 \\
AT & 68 & 159 & 91 \\
HZ & 75 & 168 & 93 \\
RP & 83 & 147 & 64 \\
YN & 98 & 168 & 70 \\
\hline
\end{tabular}

diberikan pekerjaan rumah (home work) untuk dapat melatih pemahaman siswa di rumah. Nantinya pekerjaan siswa tersebut akan dibahas pada pertemuan selanjutnya.

Pertemuan pertama membahas mengenai kepercayaan diri dalam penampilan diri. Siswa diberikan kesempatan untuk menyampaikan pengalaman atau kejadian yang dialami berhubungan dengan kepercayaan diri dalam penampilan diri. Kegiatan selama pelaksanaan konseling kelompok yang pertama secara lebih rinci disajikan dalam tabel 2.

Pertemuan kedua membahas kepercayaan diri dalam berpikir positif. Siswa diberikan kesempatan untuk menyampaikan pengalaman atau kejadian yang dialami berhubungan dengan kepercayaan diri dalam berfikir positif. Penjelasan kegiatan lebih rinci selama pelaksanaan konseling kelompok yang kedua disajikan pada tabel 3 .

Pertemuan ketiga membahas kepercayaan diri dalam ketrampilan komunikasi. Pertemuan ketiga membahas kepercayaan diri dalam ketrampilan komunikasi. Siswa diberikan kesempatan untuk menyampaikan pengalaman atau kejadian yang dialami berhubungan dengan kepercayaan diri dalam ketrampilan komunikasi. Penjelasan kegiatan lebih rinci selama pelaksanaan konseling kelompok yang ketiga disajikan pada tabel 4.

\section{Data Kuantitatif}

Analisis kelompok yang digunakan adalah analisis hasil dan proses. Analisis hasil dilakukan dengan menghitung skor inventori kepercayaan diri sebelum dan sesudah treatment secara keseluruhan. Sedangkan analisis proses dilakukan dengan cara meghitung perubahan rata-rata kelompok pada tiap-tiap konseling. Perubahan skor pretest dan posttest dari masing-masing siswa disajikan pada tabel 5. 


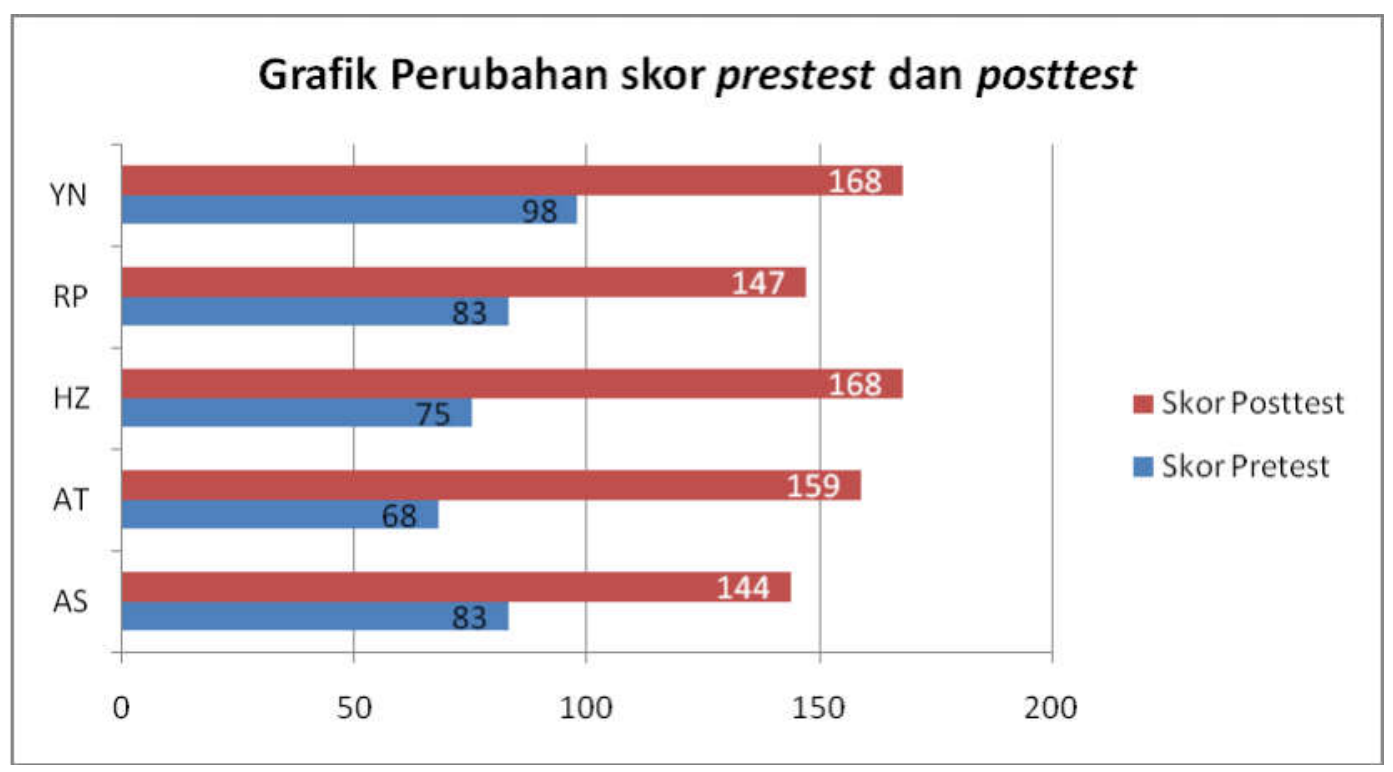

\section{Gambar 1 Grafik Perubahan Skor Pretest dan Posttest}

Skor keseluruhan subjek penelitian diperoleh dari skor inventori kepercayaan diri yang dilakukan melalui pretest dan posttest keseluruhan aspek kepercayaan diri. Rata-rata hasil pretest dari 5 siswa adalah 81,4 dan hasil rata-rata hasil posttest adalah 157,2 dengan nilai minimum pretest adalah 68 dan posttest adalah 144, serta nilai maksimum pretest adalah 98 dan posttest adalah 168. Perbedaan skor hasil pretest dan posttest disajikan dalam bentuk grafik pada gambar 1.

\section{Pengujian Hipotesis}

Pengujian hipotesis dilakukan dengan menggunakan uji Wilcoxon skor pretest dan posttest. Tujuan dari pengujian ini adalah untuk membuktikan hipotesis penelitian. Apakah teknik self-instruction dapat dikatakan efektif meningkatkan kepercayaan diri jika nilai rata-rata rangking setelah diberikan konseling kelompok lebih tinggi dari pada nilai rata-rata rangking sebelum pemberian konseling kelompok dan hasil uji Wilcoxon menunjukkan perbedaan antara hasil pretest dan posttest. Nilai Wilcoxon sebesar $\left(\mathrm{z}=-2.023^{\mathrm{a}}\right)$ dengan nilai Asymp. Sig. (2-tailed) untuk uji dua sisi adalah 0,043. Signifikasi di bawah $0,05(0,043<0,05)$ menunjukkan bahwa $\mathrm{H}_{0}$ ditolak, sehingga dapat disimpulkan bahwa teknik selfinstruction efektif untuk meningkatkan kepercayaan diri siswa.

\section{SIMPULAN DAN SARAN}

\section{Simpulan}

Penelitian ini menunjukkan bahwa terdapat perbedaan tingkat kepercayaan diri pada 5 siswa yang dijadikan subjek penelitian. Perbedaan tersebut yakni adanya peningkatan skor angket setelah pemberian treatment berupa konseling kelompok dengan teknik self-instruction. Seluruh anggota kelompok mampu meningkatkan skor angketnya dengan cukup signifikan, di samping juga mampu meningkatkan tingkat kepercayaan diri dari tingkat rendah ke tinggi, meningkatnya skor ini menyatakan ketepatan hipotesis penelitian yang ditentukan dan menandai keefektifan teknik self instruction dalam meningkatkan kepercayaan diri siswa. 


\section{Saran}

Berdasarkan pada kesimpulan dalam penelitian eksperimen dalam konseling kelompok dengan teknik self-instruction untuk meningkatkan kepercayaan diri siswa, maka peneliti mengajukan beberapa saran yang dapat dipertimbangkan: (1) Konselor diharapkan membantu siswa untuk meningkatkan kepercayaan diri dengan mengembangkan teknik self-instruction dalam praktik layanan konseling kepada siswa-siswa yang memiliki kepercayaan diri rendah. (2) Peneliti selanjutnya jika ingin melakukan penelitian lanjutan disarankan untuk memperluas variasi teknik yang digunakan dalam konseling kelompok utnuk meningkatkan kepercayaan diri siswa, serta memperluas subjek penelitian di wilayah sekolah-sekolah di Kota Malang, misalnya dengan jenjang kelas berbeda.

\section{DAFTAR RUJUKAN}

Cormier, S. \& Nurius, S.P. 2003. Interviewing and Change Strategies For Helper. Brooks/Cole. USA.

Firmansyah, R. 2012. Efektifitas Teknik Self-Instruction dalam Mereduksi Gejala Kejenuhan Belajar Siswa. Skripsi tidak diterbitkan. Bandung PPB FIP UPI.

Hurlock, E.B. 2005. Psikologi Perkembangan Suatu Pendekatan Sepanjang Rentang Kehidupan. Jakarta: Erlangga.

Lauster,P. 2008. Tes Kepribadian. Jakarta: PT Bumi Aksara.

Lindenfield, G. 1997. Mendidik Anak Agar Percaya Diri. Jakarta: Arcan.

Papalia, D. E., dkk. 2008. Human Development. Jakarta: Kencana Prenada Media Group.

Prasetyo, D.B. 2013. Keefektifan Teknik Self-Instruction untuk Menurunkan Kecemasan Menghadapi Ujian Siswa Kelas VII Sekolah Menengah Pertama. Skripsi. Malang: Tidak diterbitkan.

Rahmawati, H. 2009. Modifikasi Perilaku. Malang: LP3 Universitas Negeri Malang.

Slavin, R. E. 2008. Psikologi Pendidikan: Teori dan Praktik. Jakarta: Indeks.

Sugiarto, E. 2009. How Confident Are You?. Sidoarjo: Masmedia Buana Pustaka.

Sugiyono. 2008. Metode Penelitian Kuantitatif, Kualitatif, dan R\&D. Bandung: Alfabeta.

Sugiyono. 2010. Metode Penelitian Pendidikan Pendekatan Kuantitatif, Kualitatif, dan R\&D. Bandung: Alfabeta.

Widiyanti, A. 2013. Kefeektifan Teknik Self-Instruction untuk Meningkatkan Self-efficacy dalam Belajar Siswa Kelas VII SMP Negeri 3 Malang. Skripsi. Malang: Tidak diterbitkan. 